\title{
GRAZING REDUCES BIOMASS FLUCTUATIONS OF RANGELAND PLANTS: AN 11-YEAR COMPARISON OF GRAZING VS. ENCLOSURE
}

\author{
WANG, J. ${ }^{1}-$ ZHANG, R. Q. ${ }^{1}-$ BIYASI, A. ${ }^{1}-$ LIU, W. T. ${ }^{2 *}-$ GAO, T. M. ${ }^{1}-$ YUE, Z. W. ${ }^{1}-$ LIU, H. $^{1}-$ \\ GE, N. ${ }^{1}$ \\ ${ }^{I}$ The Institute of Water Resources for Pastoral Areas, Ministry of Water Resources, Hohhot, China \\ ${ }^{2}$ Academy of Animal Science and Veterinary Medicine, Qinghai University, Qinghai Provincial Key \\ Laboratory of Adaptive Management on Alpine Grassland, Xining, China \\ *Corresponding author \\ e-mail:qhdxlwt@163.com; phonelfax: +86-971-531-8396 \\ (Received $18^{\text {th }}$ Feb 2020; accepted $9^{\text {th }}$ Jul 2020)
}

\begin{abstract}
Enclosure age induces technical difficulties related to establishing recovery measures for degraded rangeland biomass. The long-term and continuous enclosure of a degraded rangeland may provide strong theoretical support for this practice. In this study, enclosure measures were established to monitor the plant communities in the long-term grazing rangelands of Xilamuren in the Inner Mongolian Plateau, China, for 11 years. This study found that the number of species decreased in the enclosure rangeland every year, especially the number of perennial forbs. Grazing reduced the interannual fluctuation in the plant community biomass, and enclosure increased the biomass of perennial bunchgrasses and perennial rhizomatous grasses. In the enclosure treatment, community biomass began to decrease in 2014 (an extreme drought year), and there was no significant difference in biomass between the enclosure and grazing treatments in the 11th year. Our results indicate that grazing maintains grassland species and reduces the interannual fluctuations of biomass, and enclosure increases the risks of plant communities coping with extreme drought climates.
\end{abstract}

Keywords: species, plant functional groups, community, precipitation, Inner Mongolian Plateau

\section{Introduction}

Grassland ecosystems are one of the largest ecosystems in the world (White et al., 2000). Pasture-based grazing not only provides human beings with products of direct economic value, such as meat, milk, skin, and wool, but also has the extremely important service functions of maintaining the relative constancy of atmospheric components, improving climate, maintaining the biological gene bank, and fixing $\mathrm{CO}_{2}$, soil and water conservation (Steffens et al., 2008; Reszkowska et al., 2011), among others (Sala and Paruelo, 1997; White et al., 2000). China has the third largest area of grasslands and rangelands in the world $\left(3.9 \times 10^{8}\right.$ ha, occupying $41 \%$ of the total land area of China). However, over the past half century, the sharp increase in the number of livestock and human activities have been the most important factors in reducing grassland vegetation coverage, biomass and biodiversity (White et al., 2000; Schönbach et al., 2011). Therefore, it is necessary to study the restoration and rational utilization of degraded rangelands (Nan, 2005).

Existing theory suggests that excessive livestock carrying capacity is an important cause of rangeland degradation. Therefore, the comprehensive interference of feeding, trampling and defecation of livestock can be reduced or eliminated by reducing the stocking rate of grazing livestock or encircling animal husbandry. The original degraded rangeland plant community can recuperate and promote seedling 
germination and growth to improve rangeland productivity. In theory, it should be an ideal measure for rangeland restoration. However, Ruiz-Jaen (2005) stated that most grassland recovery programs rarely last for more than $5 \mathrm{yr}$. Conversely, long-term grassland observations may be established by replacing time with space (historical background). Although this method can adequately solve the problem regarding time, there are certain hidden dangers; that is, the rangelands can vary in microenvironment, terrain, heterogeneity, climate and other factors. Thus, long-term continuous research in the same study area (grazed vs. enclosed) is needed to statistically evaluate potential differences.

Rangeland plants are also vulnerable to climatic factors, especially extreme climatic variation. Previous research has shown that the climatic characteristics from January to July were primary factors driving plant community changes (Bai et al., 2004). Westoby (1989) noted that the transition of community succession required particular rainfall events (such as rare heavy rain) to drive a change in community composition. This finding is of great interest to us, and we wondered whether extreme drought will also change the characteristics of a community during a long-term enclosure experiment. As the direct manager of rangeland plant community composition and diversity, the quantitative change of herbivores will lead to a series of cascading effects (Bai et al., 2004) of multispecies, plant functional groups and intercommunity feedback regulation in rangeland ecosystems. This has piqued our interest, and we propose that rangeland plant communities facing extreme drought will also have a significant impact, and grazing and enclosure plant communities will show different responses.

In our study, the research determine site was a severely degraded grazed rangeland. Annual dynamic changes in plant communities in long-term (11-yr) enclosed areas of the rangeland were studied to 1) frequency dynamic changes in species and plant functional groups under grazing and no grazing; (2) dynamic changes in plant functional group biomass and community biomass due to grazing and no grazing; and (3) potential factors that drive changes in community biomass.

\section{Materials and methods}

\section{Study area}

The research site was located in the Xilamuren rangeland $\left(111^{\circ} 12^{\prime} \mathrm{E}, 41^{\circ} 21^{\prime} \mathrm{N}\right)$ (desert steppe.) in Darhan Muminggan United Banner, Baotou, Inner Mongolia, China (Fig. 1). This region has a gentle topography with a mean elevation of $1468 \mathrm{~m}$. The soil type was chestnut soil with a soil organic matter layer of 5-10 cm. From 2007 to 2017, the mean annual precipitation was $273 \mathrm{~mm}$ (Table 1). Between 60 and $80 \%$ of precipitation occurred during the plant growth season (May to October). The annual evaporation was $2526 \mathrm{~mm}$. The mean temperature by month remained similar from 2007 to 2017 . The mean temperature was $4.2^{\circ} \mathrm{C}$ (maximum $38.0^{\circ} \mathrm{C}$; minimum $-39.4{ }^{\circ} \mathrm{C}$ ) (Table 1). The coverage of plant communities ranged from $39 \%$ to $68 \%$. The dominant species was Stipa krylovii (Roshev.), and the codominant species were Leymus chinensis (Trin.) and Agropyron cristatum (Linn.). Historically, rangelands were mainly used by nomads. Since the implementation of the grassland contract system in 1988, local herdsmen have changed from traditional nomadic life to long-term settled grazing. No utilization was performed between 1988 and 2006, and the enclosure experiment was initiated in 2007. 

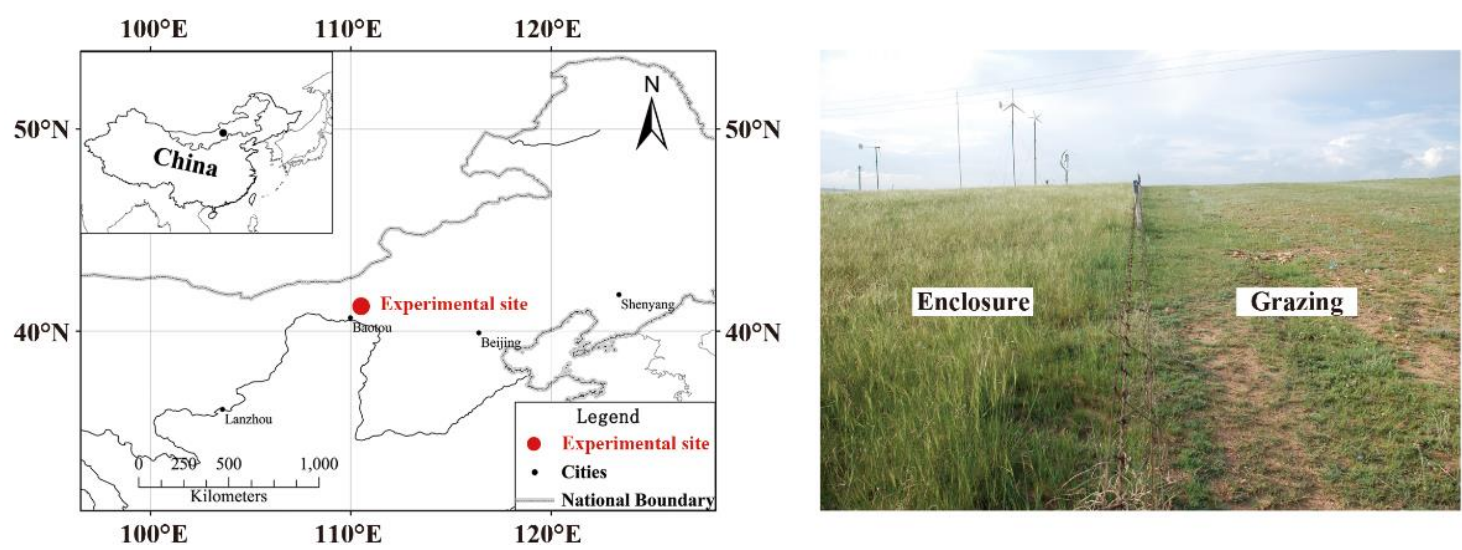

Figure 1. The location of experimental site and experiment treatment

Table 1. Annual precipitation distribution map of the study site

\begin{tabular}{c|c|c|c|c|c|c|c|c|c|c|c}
\hline Year & $\mathbf{2 0 0 7}$ & $\mathbf{2 0 0 8}$ & $\mathbf{2 0 0 9}$ & $\mathbf{2 0 1 0}$ & $\mathbf{2 0 1 1}$ & $\mathbf{2 0 1 2}$ & $\mathbf{2 0 1 3}$ & $\mathbf{2 0 1 4}$ & $\mathbf{2 0 1 5}$ & $\mathbf{2 0 1 6}$ & $\mathbf{2 0 1 7}$ \\
\hline Annual precipitation $(\mathrm{mm})$ & 231.40 & 372.70 & 200.20 & 274.90 & 258.60 & 442.30 & 278.10 & 184.95 & 265.20 & 264.80 & 228.00 \\
\hline $\begin{array}{c}\text { Average temperature of } \\
\text { plant growing season }\left({ }^{\circ} \mathrm{C}\right)\end{array}$ & 19.19 & 20.24 & 19.59 & 18.44 & 19.05 & 19.64 & 18.61 & 19.47 & 19.86 & 19.55 & 19.88 \\
\hline
\end{tabular}

\section{Study site setting}

For the enclosure treatment, three 40 ha enclosures were established in the rangeland in early May 2007. No livestock entered these enclosures during the 11-yr period. Sites were selected for similarity of natural habitat factors, including slope and slope aspect. For the grazed treatment, three sites were closed to the enclosure treatments, and each site area was 40 ha. For the grazed treatment, three 40-ha sites were selected close to the enclosure treatments. Grazing was by sheep only, and the stocking rate of each site was 0.30 sheep $\mathrm{ha}^{-1}$ month $^{-1}$, resulting in a 50 to $55 \%$ grass utilization rate (Wang et al., 2014). Sites were similar in topography and landforms to the enclosure sites. Grazing took place from May to October every year. In the evening, the flock was allowed in the site, with no supplementary feeding.

\section{Sampling method}

Changes in vegetation were determined in August, which is the peak biomass in desert rangelands. To determine the biomass of each plant species present, ten $1 \mathrm{~m}^{2}$ quadrats were regularly placed along the transect in a Z-shaped orientation. The transect lines were $200 \mathrm{~m}$ long and laid $5 \mathrm{~m}$ away from the boundary enclosure to avoid edge effects. Along each transect, $1 \mathrm{~m}^{2}$ quadrats were laid at intervals of $20 \mathrm{~m}$. For each quadrat, live and dead aboveground biomass was clipped at the ground level, and dead parts were removed (Bai et al., 2012). Plants were clipped by species in each quadrat and numbered. The fresh materials were brought back to the laboratory and put in an oven at $105{ }^{\circ} \mathrm{C}$ for $10 \mathrm{~min}$. Then, samples were dried to constant weight in a drying cabinet at $65^{\circ} \mathrm{C}$, and finally, the dry sample was weighed. A total of 60 quadrats were investigated each year. The data for this study were collected from 2007 to 2017, with 660 quadrats in total. 


\section{Plant functional groups}

According to the existing literature and the plant types in the experimental fields, plants were divided into five functional groups (Bai et al., 2004): perennial bunchgrasses, perennial rhizomatous grasses, perennial forbs, shrubs and subshrubs, and annual or biennial herbs (Table 2).

Table 2. Existing plants of the study site

\begin{tabular}{|c|c|c|c|c|c|}
\hline $\begin{array}{l}\text { Species } \\
\text { code }\end{array}$ & Species name & $\begin{array}{l}\text { Plant functional } \\
\text { groups }\end{array}$ & $\begin{array}{l}\text { Species } \\
\text { code }\end{array}$ & Species name & $\begin{array}{c}\text { Plant functional } \\
\text { groups }\end{array}$ \\
\hline 1 & Stipa krylovii & PB & 31 & Iris tenuifolin & $\mathrm{PF}$ \\
\hline 2 & Cleistogenes squarrosa & PB & 32 & Chamaerhodos trifida & $\mathrm{PF}$ \\
\hline 3 & Agropyron cristatum & PB & 33 & Thalictrum petaloideum & $\mathrm{PF}$ \\
\hline 4 & Koeleria cristata & PB & 34 & Allium bidentatum & $\mathrm{PF}$ \\
\hline 5 & Cleistogenes songorica & PB & 35 & Polygala tenuifolia & $\mathrm{PF}$ \\
\hline 6 & Stipa breviflora & PB & 36 & Iris lactea & $\mathrm{PF}$ \\
\hline 7 & Leymus chinensis & PR & 37 & Haplophyllum dauricum & $\mathrm{PF}$ \\
\hline 8 & Kochiaprostrata & SS & 38 & Oxytropis leptophylla & $\mathrm{PF}$ \\
\hline 9 & Ptilotricum canescens & SS & 39 & Carex duriuscula & $\mathrm{PF}$ \\
\hline 10 & Thymus mongolicus & SS & 40 & Cirsium setosum & $\mathrm{PF}$ \\
\hline 11 & Caragana stenophylla & SS & 41 & Astragalus galactites & $\mathrm{PF}$ \\
\hline 12 & Artemisia frigida & $\mathrm{PF}$ & 42 & Taraxacum mongolicum & $\mathrm{PF}$ \\
\hline 13 & Heteropappus altaicus & $\mathrm{PF}$ & 43 & Allium tenuissimum & $\mathrm{PF}$ \\
\hline 14 & Allium mongolicum & $\mathrm{PF}$ & 44 & Leymus secalinus & $\mathrm{PF}$ \\
\hline 15 & Hedysarum brachypterum & $\mathrm{PF}$ & 45 & Scorzonera pseudodivaricata & $\mathrm{PF}$ \\
\hline 16 & Convolvulus ammannii & $\mathrm{PF}$ & 46 & Phlomis dentosa & $\mathrm{PF}$ \\
\hline 17 & Stellera chamaejasme & $\mathrm{PF}$ & 47 & Lappula myosotis & $\mathrm{AB}$ \\
\hline 18 & Artemisia argyi & $\mathrm{PF}$ & 48 & Plantago depressa & $\mathrm{AB}$ \\
\hline 19 & Bupleurum scorzonerifolium & $\mathrm{PF}$ & 49 & Chenopodium aristatum & $\mathrm{AB}$ \\
\hline 20 & Arenaria juncea & $\mathrm{PF}$ & 50 & Eragrostis pilosa & $\mathrm{AB}$ \\
\hline 21 & Potentilla verticillaris & $\mathrm{PF}$ & 51 & Artemisia anethifolia & $\mathrm{AB}$ \\
\hline 22 & Cymbaria dahurica & $\mathrm{PF}$ & 52 & Corispermum declinatum & $\mathrm{AB}$ \\
\hline 23 & Potentilla bifurca & $\mathrm{PF}$ & 53 & Neopallasia pectinata & $\mathrm{AB}$ \\
\hline 24 & Gentiana dahurica & $\mathrm{PF}$ & 54 & Chenopodium iljinii & $\mathrm{AB}$ \\
\hline 25 & Androsace incana & $\mathrm{PF}$ & 55 & Orostachys fimbriatus & $\mathrm{AB}$ \\
\hline 26 & Potentilla acaulis & $\mathrm{PF}$ & 56 & Euphorbia humifusa & $\mathrm{AB}$ \\
\hline 27 & Potentilla tanacetifolia & $\mathrm{PF}$ & 57 & Lepidium apetalum & $\mathrm{AB}$ \\
\hline 28 & Melissilus ruthenicus & $\mathrm{PF}$ & 58 & Salsola collina & $\mathrm{AB}$ \\
\hline 29 & Dracocephalum heterophyllum & $\mathrm{PF}$ & 59 & Chenopodium glaucum & $\mathrm{AB}$ \\
\hline 30 & Sibbaldia adpressa & $\mathrm{PF}$ & & & \\
\hline
\end{tabular}

PB, perennial bunchgrasses; PR, perennial rhizome grass; SS, shrub and semishrubs; PF, perennial forbs; and $\mathrm{AB}$, annuals and biennials

\section{Statistical analysis}

Independent sample t-tests were used to examine and compare the plant community biomass, biomass of each functional group and biological differences in dominant species in the enclosure and grazing rangelands in the same year. Analysis was completed in SAS 9.0 (SAS Institute Inc., Cary NC, USA).

A regression equation was constructed between community biomass and grazing treatment, annual precipitation, perennial bunchgrasses, perennial rhizomatous grasses, perennial forbs, shrubs and subshrubs, and annual or biennial herbs by using partial 
least squares. According to the obtained regression equation, variables important in prediction $(V I P)$ can be identified.

$$
V I P_{\mathrm{j}}=\sqrt{\frac{q \sum_{h=1}^{m} r^{2}\left(Y, t_{h}\right) w_{h j}^{2}}{\sum_{h=1}^{m} r^{2}\left(Y, t_{h}\right)}}
$$

In Equation 1, $q$ is the number of independent variables, $r\left(Y, t_{h}\right)$ is the covariance of two observational variables, and $w_{h j}$ is component $j$ of axis $w_{h}$.

The larger the VIP of the independent variable is, the stronger the effect of the independent variable on the community biomass. If the VIP of the independent variable is $>1$, the independent variable is considered an important index that affects the community biomass, and if the VIP of the independent variable is $<0.5$, the independent variable is considered an unimportant index that does not affect the community biomass (Li et al., 2015). The above statistical analysis was completed in SAS 9.0 (SAS Institute Inc., Cary NC, USA).

To further analyze factors driving biomass changes in rangeland plant communities, we selected variables with $V I P>1$ and defined these variables as observable variables, and we defined plant functional groups as potential variables. A structural equation model was constructed for statistical analysis with the maximum likelihood as the estimation method (Bansal et al., 2014). The above statistical analysis was completed in Amos 20 (IBM, SPSS, Armonk, NY, USA).

\section{Results}

\section{Frequencies of species and functional groups}

Fifty-nine plant species were found in the 11 years of field observation, among which the frequencies of Stipa krylovii, Cleistogenes squarrosa, Agropyron cristatum and Convolvulus ammannii were always higher than 0.1 (Fig. 2). First, compared with grazed rangeland, frequencies of Artemisia frigida, Heteropappus altaicus and Allium mongolicum Regel in the enclosure treatment decreased year by year, which is contrary to patterns observed for Koeleria cristata var. poaeformis and Salsola collina. Second, the total numbers of plant species decreased every year under the grazing treatment (Fig. 2), while the numbers of plant species remained stable at approximately 10 species under the grazing treatment. From the perspective of plant functional groups, the frequencies of perennial bunchgrasses were always higher than 0.8 in the 11 years. Compared with the enclosure treatment, interannual changes in the frequency of perennial rhizomatous grasses were relatively higher under the grazing treatment than under the enclosure treatment. This is opposite to patterns observed for annual and biennial herbs.

\section{Biomass of common species, plant functional groups and communities}

Over the 11 years, Stipa krylovii, Cleistogenes squarrosa, Agropyron cristatum and Convolvulus ammannii were all found in both grazed and enclosed treatments. The biomass of Stipa krylovii was higher under the enclosure treatment than under the grazed treatment $(P<0.01)$, which reached a maximum value in 2012 (Fig. 3). The 
range of fluctuation in interannual biomass of the common species under the grazed treatment was lower than when enclosure was allowed. Additionally, Stipa krylovii, Cleistogenes squarrosa, and Agropyron cristatum are perennial bunchgrasses. The results of the plant functional groups showed that the biomass of perennial bunchgrasses and perennial rhizomatous grasses significantly increased in the enclosure treatment. However, the biomass of perennial forbs decreased (Fig. 4). Community biomass results showed that ranges of interannual fluctuations of community biomass were similar under the grazing and enclosure treatments. The community biomass maximum value in 2012 was over 600\% higher than that in 2017 (minimum value), where enclosure occurred, but the community biomass under grazing was relatively low. However, the range of interannual fluctuation in community biomass under grazed treatment was relatively lower than when enclosure occurred. In the first $10 \mathrm{yrs}$, community biomass under the enclosure treatment was significantly higher than that under the grazed treatment $(P<0.01)$, but there was no significant difference between the two treatments in the 11th year; however, community biomass in the enclosure treatment began to decrease in 2014.

\section{Biomass of plant functional groups and communities between 2007 and 2017}

The results of the independent sample $t$ test showed that over the 11 years, the community biomass under enclosure decreased $41.17 \%(\mathrm{P}<0.05)$. The difference was mainly reflected in the perennial bunchgrasses and perennial rhizome grasses. Compared with the perennial bunchgrasses and perennial rhizome grasses in 2007, the perennial bunchgrasses and perennial rhizome grasses decreased $26.61 \%$ and $49.56 \%(\mathrm{P}<0.05)$ in 2017. However, under the grazing treatment, there was no significant difference between the biomass of communities and functional groups in 2007 and 2017 (Fig. 5).

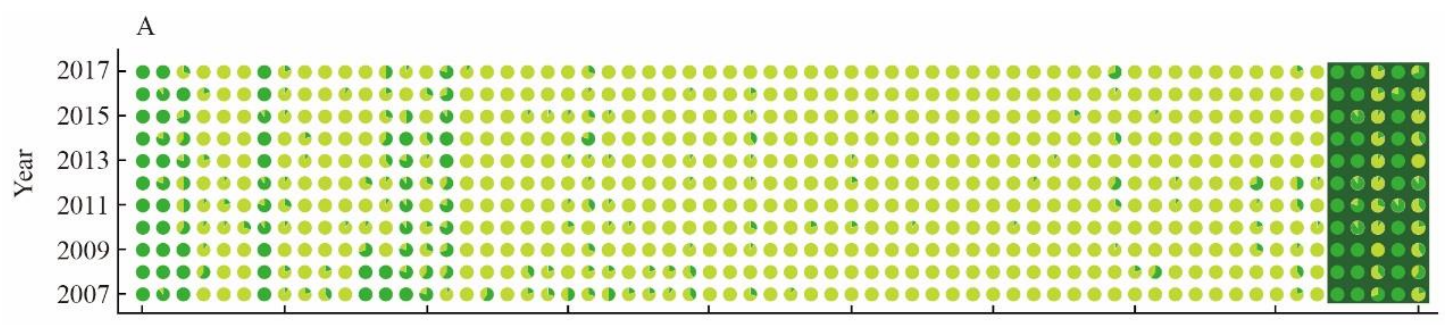

B

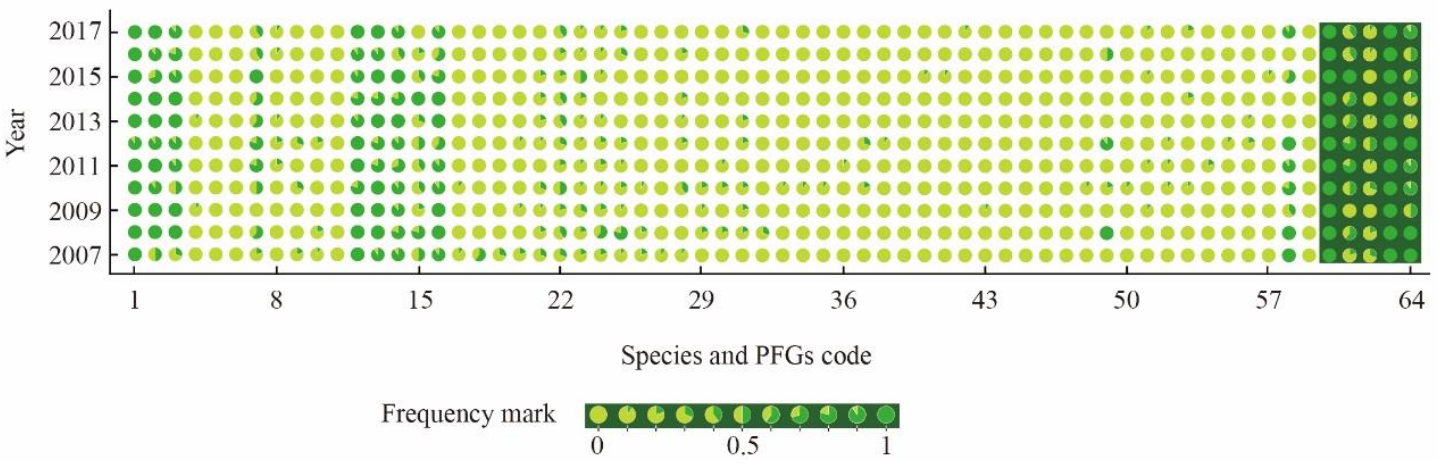

Figure 2. Interannual variability in the frequencies of species and functional groups. $A$ and $B$ indicate enclosure and grazing, respectively. Codes 1-59 indicate the plant species; see Table 2 for details. Codes 60-64 (green shadow) indicate perennial bunchgrasses, perennial rhizome grasses, shrubs and semishrubs, perennial forbs, and annuals and biennials 

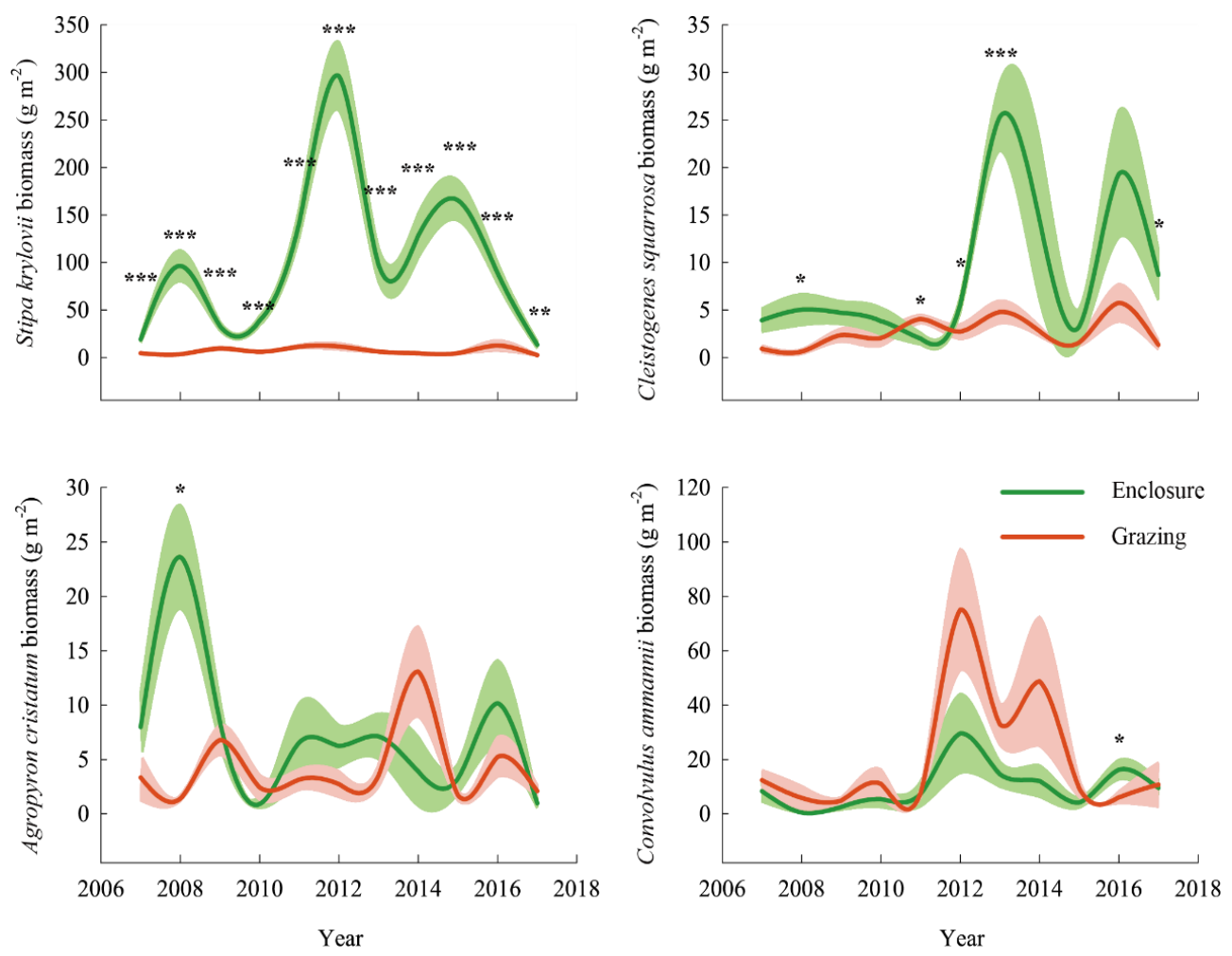

Figure 3. Annual variation in the biomass of dominant plant species under enclosure and grazing treatments. The shadowed part represents the standard error. *, $P<0.05$; **, $P<0.01 ; * * *, P<0.0001$

\section{Driving factors for biomass}

Regression equations were constructed between community biomass and five plant functional groups, annual precipitation and grazing treatment by using partial least squares, which were used to calculate the VIP value for each factor that drives the changes in community biomass. The results showed that perennial bunchgrasses, perennial rhizomatous grasses, precipitation and grazing were important indexes (VIP > 1) that affected changes in community biomass (Fig. 6A). The selected indexes were used to construct the structural equation model in this study as indicated by nonsignificant $\mathrm{P}$ values (Fig. 6). The results of this model showed that grazing had a negative effect on the biomass of the plant functional groups and indirectly affected the community biomass $\left(R^{2}=0.90\right)$ (Fig. 6B). However, precipitation had a positive effect on the biomass of the plant functional groups and indirectly affected the community biomass.

\section{Discussion}

Compared with the grazed rangeland, the numbers of species in the enclosure plant communities decreased every year, which is in contrast to the results of other studies (Loeser et al., 2007; Liu et al., 2016, 2017). These differences may be caused by the following factors: a) Dominant species: the competitive advantages of the dominant species significantly increased when grazing was excluded, which increased the biomass of perennial bunchgrasses and perennial rhizomatous grasses, especially bunchgrasses (e.g., S. krylovii, C. squarrosa and L. chinensis). Moreover, when this 
rangeland is supplied limited resources, increases in dominant species inevitably lead to decreases in survival chances of other species (e.g., A. frigida, H. altaicus and $A$. mongolicum Regel). In addition, in the grazing treatment, the biomass of perennial bunch grasses was always at a low level, which may be related to the selective feeding of herbivores and the palatability of the plants themselves. Koerner et al. (2018) suggests that when herbivores reduce the abundance (biomass, coverage) of dominant species (for example, because dominant plants are delicious), additional resources can be used to support new species, thereby increasing biodiversity. b) Habitat homogenization: Livestock disturbance causes rangeland to produce a variety of habitat patches to ensure that plant species in different successional stages will coexist; however, large livestock disturbances were removed from the enclosed rangeland, which resulted in habitat homogenization, resulting in a decrease in the number of species. c) Species migration: Under grazed treatment, plant seeds can spread effectively with the help of anemophily (wind), insects and large herbivores, increasing the chances of survival of the species, which in turn increases the number of species. Under enclosure treatment, the spread of plant seeds can occur only through anemophily or insects, which greatly limits the spread of species. In this study, the biomass of $S$. krylovii under the grazing treatment was $3496 \%$ higher than that under the enclosure treatment. The spatial distribution data are not presented in this study, but in the $1 \mathrm{~m}^{2}$ quadrat, the biomass of S. krylovii reached 296.19 $\pm 36.00 \mathrm{~g}$ in 2012, and limited spatial dispersion (small-scale diffusion) could have caused strong spatial aggregation of the population. The aggregation of plants caused by limited spatial transmission can make the population appear to have a patchy distribution (Webb and Peart, 2000). However, the occurrence of small-scale plant aggregations in relatively harsh habitats may lead to competition and self-thinning of plants (Javier, 2012) and may even lead to the death of young plants, leading to a decrease in the number of species in the enclosure communities every year.

Enclosure increased community biomass, which was mainly because disturbance by foraging, trampling and defecation of livestock was eliminated by enclosing the rangeland. Thus, dominant species in the community that were previously strongly impacted by livestock could quickly exert their competitive advantages to change the species composition of the community. Related results have shown that fencing enclosures increased the biomass of grassland plant communities (Han et al., 2015; Kohyani et al., 2011; Lu et al., 2015). However, in our study, we found that the range of fluctuation in the interannual biomass of plant communities under grazing was relatively lower than that of plant communities in the enclosure treatment because livestock disturbance may stimulate supercompensation effects in plants that drive them to conduct an effective carbon assimilation process. In addition, during long-term livestock disturbance, plant communities may be in the "intermediate disturbance" stage, which reduces competition effects of specific plants in the plant communities, enables nondominant species to utilize growth space (Altesor et al., 2005), and increases community biomass, which is consistent with the results of this study. From the perspective of plant functional groups, the structural equation model also shows that grazing livestock can indirectly regulate the biomass of plant communities by affecting plant functional groups, such as perennial bunchgrasses and perennial rhizomatous grasses, thus releasing competition among different plant functional groups. It makes it in a relatively stable state for a long time, which verifies the hypothesis of a compensation effect between functional groups in the community (Bai et al., 2004). 

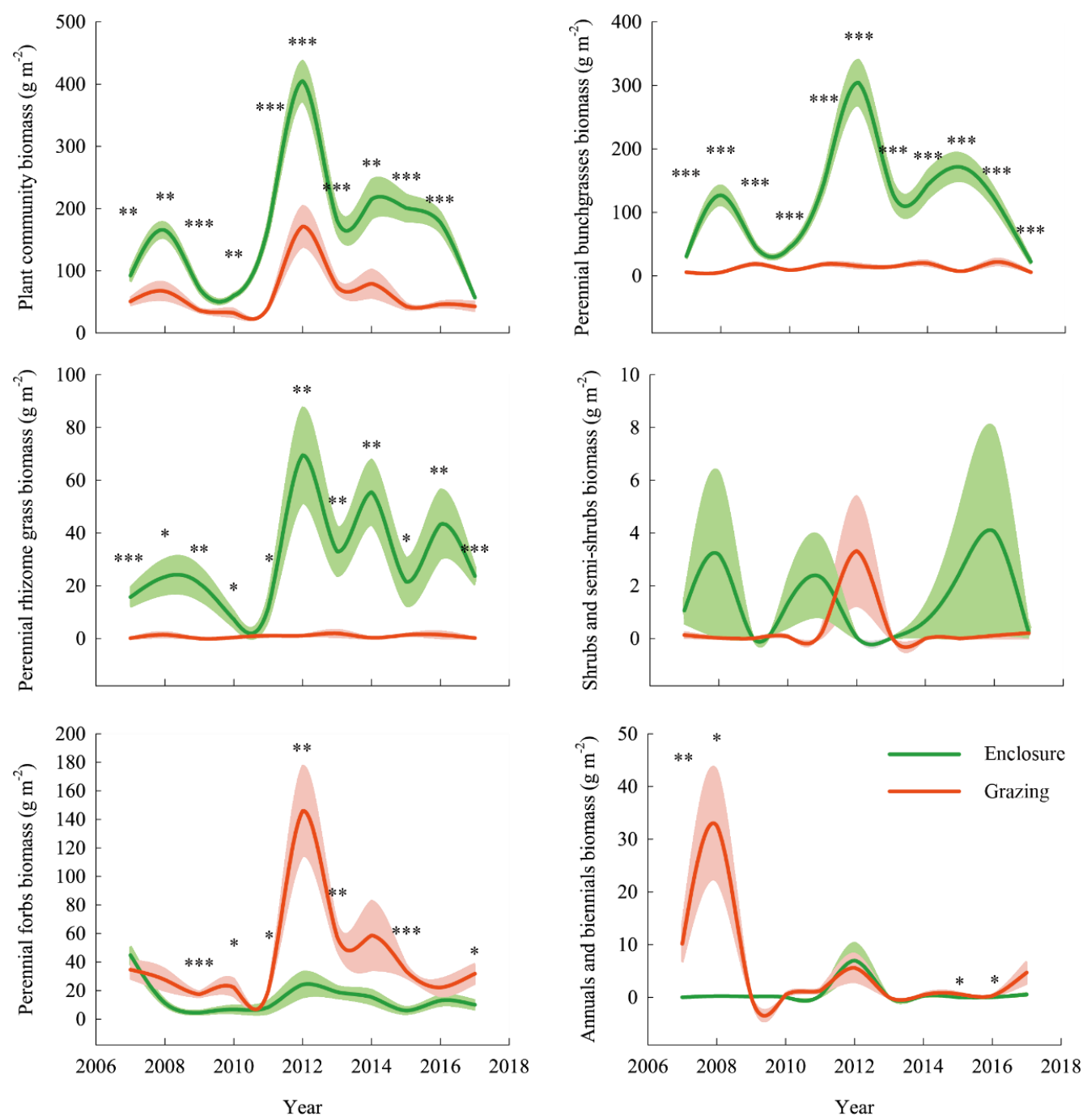

Figure 4. Annual variations in plant functional groups and community biomass under enclosure and grazing treatments. The shadowed part represents the standard error. *, $P<0.05$; **, $P<0.01 ; * * *, P<0.0001$
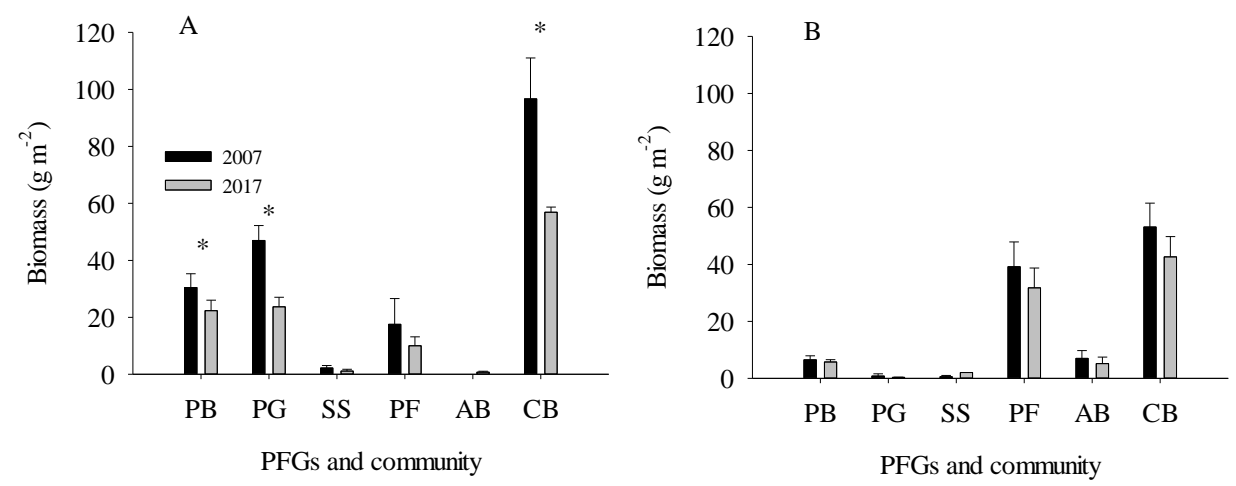

Figure 5. Biomass of community and functional groups under enclosure and grazing in 2007 and 2017. $A$ and $B$ indicate enclosure and grazing, respectively. $P B, P G, S S, P F, A B, C B$ indicate perennial bunchgrasses, perennial rhizome grasses, shrubs and semishrubs, perennial forbs, and annuals and biennials and community. * indicates a significant difference between 2007 and 2017. No mark indicates no difference between 2007 and 2017 

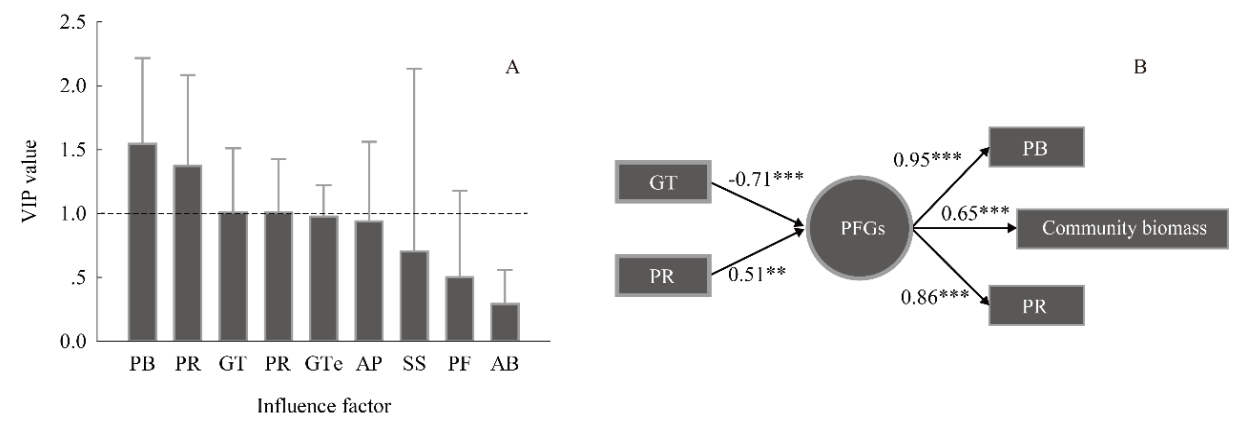

Figure 6. Screening of the factors driving the changes in biomass and the final structural equation model of biomass. The results of the structural equation model fitting: $\chi^{2}=2.833$, $d f=5, P=0.051$. $P B$, perennial bunchgrasses; $P R$, perennial rhizomatous grasses; $P F$, perennial forbs; SS, shrubs and subshrubs; AB, annual or biennial herbs; GT, grazing treatment; AP, annual precipitation; PFGs, plant functional groups; PR, precipitation; GTe, average temperature of the plant growing season

By screening the important indexes that affect community biomass, we found that grazing affected community biomass. However, we also found that biomass fluctuations always increased and decreased with changes in annual precipitation, and excluding grazing increased the effect of annual precipitation on rangeland plants (Wang et al., 2014). Further analysis showed that the community biomass where grazing was excluded was higher than that under the grazed treatment from 2007 to 2016, and there was no difference between the two treatments in 2017. However, the community biomass in enclosure areas began to decrease in 2014. These data are similar to the research results of Bai et al. (2004). The biomass of rangeland plants decreases during extreme drought years and cannot be effectively increased in the following several years except after extreme precipitation (Westoby, 1989). This impact may be because in the Inner Mongolian desert grassland where there are four distinct seasons, the aboveground branches of perennial bunchgrasses usually survive only one growing season, while underground organs can survive for many years (Li et al., 2012). These underground vegetative organs (bud banks) play a decisive role in the reproduction and survival of plant populations (Hartnett et al., 2006). However, extreme droughts can cause devastating damage to underground organs. In addition, under such drought conditions, the quantity of microorganisms decreases, their activity weakens, and the mineralization rate and fluxes of carbon and nitrogen in the soil decrease significantly (Bloor and Bardgett, 2012). This in turn affects the growth, development, and reproduction of rangeland plants so that they cannot be restored for a long time. This result provides a warning that long-term exclusion of livestock seems to increase vulnerability when extreme drought occurs, and if these rangelands face successive years of drought or long-term drought, plant communities that have remained enclosed for long periods of time will be more vulnerable than those in grazed rangelands, which may result in more severe degeneration. That is, excluding grazing may increase the risks of plant communities coping with global changes.

\section{Conclusion}

Based on the analysis of the plant community biomass in grazed and enclosed rangelands for 11 consecutive years in Inner Mongolia, it is concluded that grazing 
reduces plant community biomass and the range of interannual fluctuation in biomass, while enclosure increases the biomass of perennial bunchgrasses and perennial rhizomatous grasses, and the difference was mainly reflected in the perennial bunchgrasses and perennial rhizome grasses. Therefore, it is of great significance for the ecology and management of desert grassland to set a reasonable enclosure. In addition, precipitation had a positive effect on the biomass of the plant functional groups and indirectly affected the community biomass. Our results also indicated that in the face of extreme climate, enclosure increases the impact of extreme precipitation on plant communities and increases risks associated with extreme drought conditions. This indicated that in the face of future climate change, especially precipitation and seasonal changes, long-term enclosure is not an appropriate measure for rangeland restoration.

Acknowledgements. The authors thank Tianming Gao who assisted with fieldwork and data collection. This work was supported by the Inner Mongolia science and technology projects (201701024), and the Academy of water sciences special projects of China (MK2017J05, MK2016J05).

Conflict of interests. The authors declare that they have no conflict of interests.

\section{REFERENCES}

[1] Altesor, A., Oesterheld, M., Leoni, E., Lezama, F., Rodríguez, C. (2005): Effect of grazing on community structure and productivity of a Uruguayan grassland. - Plant Ecology 179: 83-91.

[2] Bai, Y., Han, X., Wu, J., Chen, Z., Li, L. (2004): Ecosystem stability and compensatory effects in the Inner Mongolia grassland. - Nature 431: 181-4.

[3] Bansal, S., Sheley, R. L., Blank, B., Vasquez, E. A. (2014): Plant litter effects on soil nutrient availability and vegetation dynamics: changes that occur when annual grasses invade shrub-steppe communities. - Plant Ecology 215: 367-378.

[4] Bloor, J. M., Bardgett, R. D. (2012): Stability of above-ground and below-ground processes to extreme drought in model grassland ecosystems: interactions with plant species diversity and soil nitrogen availability. - Perspectives in Plant Ecology, Evolution and Systematics 14: 193-204.

[5] Han, J., Chen, J., Xia, J., Li, L. (2015): Grazing and watering alter plant phenological processes in a desert steppe community. - Plant Ecology 216: 599-613.

[6] Hartnett, D. C., Setshogo, M. P., Dalgleish, H. J. (2006): Bud banks of perennial savanna grasses in Botswana. - African Journal of Ecology 44: 256-263.

[7] Javier, Rodríguez-Pérez., Wiegand, T., Traveset, A. (2012): Adult proximity and frugivore's activity structure the spatial pattern in an endangered plant. - Functional Ecology 26: 1221-1229.

[8] Koerner, S. E., Smith, M. D., Burkepile, D. E., Hanan, N. P., Avolio, M. L., Collins, S. L., Knapp, A. K., Lemoine, N. P., Forrestel, E. J., Eby, S., Thompson, D. I., AguadoSantacruz, G. A., Anderson, J. P., Anderson, T. M., Angassa, A., Bagchi, S., Bakker, E. S., Bastin, G., Baur, L. E., Beard, K. H., Beever, E. A., Bohlen, P. J., Boughton, E. H., Canestro, D., Cesa, A., Chaneton, E., Cheng, J., D'Antonio, C. M., Deleglise, C., Dembélé, F., Dorrough, J., Eldridge, D. J., Fernandez-Going, B., Fernández-Lugo, S., Fraser, L. H., Freedman, B., García-Salgado, G., Goheen, J. R., Guo, L., Husheer, S., Karembé, M., Knops, J. M. H., Kraaij, T., Kulmatiski, A., Kytöviita, M., Lezama, F., Loucougaray, G., Loydi, A., Milchunas, D. G., Milton, S. J., Morgan, J. W., Moxham, C., Nehring, K. C., Olff, H., Palmer, T. M., Rebollo, S., Riginos, C., Risch, A., Rueda, M., Sankaran, M., Sasaki, T., Schoenecker, K. A., Schultz, N. L., Schütz, M., Schwabe, A., Siebert, F., Smit, C., Stahlheber, K. A., Storm, C., Strong, D. J., Su, J., Tiruvaimozhi, Y. 
V., Tyler, C., Val, J., Vandegehuchte, M. L., Veblen, K. E., Vermeire, L. T., Ward, D., Wu, J., Young, T., Yu, Q., Zelikova, T. J. (2018): Change in dominance determines herbivore effects on plant biodiversity. - Nature Ecology \& Evolution 2: 1925-1932.

[9] Kohyani, P. T., Bossuyt, B., Bonte, D., Hoffmann, M. (2011): Grazing impact on plant spatial distribution and community composition. - Plant Ecology and Evolution 144: 1928.

[10] Li, H., Yang, Y., Zhao, Y. (2012): Bud banks of two dominant grass species and their roles in restoration succession series of a flooded meadow. - Polish Journal of Ecology 60: 535-543.

[11] Li, X., Liu, Z., Wang, Z., Wu, X., Li, X., Hu, Jing., Shi, H., Guo, F., Zhang, Y., Hou, X. (2015): Pathways of Leymus chinensis individual aboveground biomass decline in natural semiarid grassland induced by overgrazing: a study at the plant functional trait scale. Plos One 10: e0124443.

[12] Liu, W. T., Wei, Z. J., Lü, S. J., Sun, S. X., Jia, L. J., Zhang, S., Wang, T. L., Dai, J. Z., Lu, Z. H. (2016): Response mechanism of plant diversity to herbivore foraging in desert grassland. - Chinese Journal of Plant Ecology 40: 564-573.

[13] Liu, W. T., Wei, Z. J., Lü, S. J., Wang, T. L., Zhang, S. (2017): The impacts of grazing on plant diversity in Stipa breviflora desert grassland. - Acta Ecologica Sinica 37: 33943402 .

[14] Loeser, M. R. R., Sisk, T. D., Crews, T. E. (2007): Impact of grazing intensity during drought in an Arizona grassland. - Conservation Biology the Journal of the Society for Conservation Biology 21: 87-97.

[15] Lu, X., Yan, Y., Sun, J., Zhang, X., Chen, Y., Wang, X., Cheng, G. (2015): Carbon, nitrogen, and phosphorus storage in alpine grassland ecosystems of Tibet: effects of grazing exclusion. - Ecology and Evolution 5: 4492-4504.

[16] Nan, Z. (2005). The grassland farming system and sustainable agricultural development in China. - Grassland Science 51: 15-19.

[17] Reszkowska, A., Krümmelbein, J., Peth, S., Horn, R., Zhao, Y., Gan, L. (2011): Influence of grazing on hydraulic and mechanical properties of semiarid steppe soils under different vegetation type in Inner Mongolia, China. - Plant and Soil 340: 59-72.

[18] Ruiz-Jaen, M. C., Aide, T. M. (2005): Restoration success: how is it being measured? Restoration Ecology 13: 569-577.

[19] Sala, O. E., Paruelo, J. M. (1997): Ecosystem Services in Grasslands. - In: Daily, G. C. (ed.) Nature's Services: Societal Dependence on Natural Ecosystems. Island Press, Washington, DC.

[20] Schönbach, P., Wan, H. W., Gierus, M., Bai, Y. F., Müller, K., Lin, L. J., Susenbeth, A., Taube, F. (2011): Grassland responses tograzing: effects of grazing intensity and managementsystem in an Inner Mongolian steppe ecosystem. - Plant and Soil 340: 103115 .

[21] Steffens, M., Kölbl, A., Totsche, K. U., Kögel-Knabner, I. (2008): Grazing effects on soil chemical and physical properties in a semiarid steppe of Inner Mongolia (P. R. China). Geoderma 143: 63-72.

[22] Wang, Z., Jiao, S., Han, G., Zhao, M., Ding, H., Zhang, X., Wang, X., Ayers, E. L., Willms, W. D., Havsatad, K., Lata, A., Liu, Y. (2014): Effects of stocking rate on the variability of peak standing crop in a desert steppe of Eurasia Grassland. - Environmental Management 53: 266-273.

[23] Webb, C. O., Peart, D. R. (2000): Habitat associations of trees and seedlings in a Bornean rain forest. - Journal of Ecology 88: 464-478.

[24] Westoby, M. (1989): Opportunistic management for rangelands not at equilibrium. Journal of Range Management 42: 266-274.

[25] White, R., Murray, S., Rohweder, M. (2000): Pilot Analysis of Global Ecosystems: Grassland Ecosystems. - World Resources Institute, Washington DC. 